\title{
Inguinal Hernia Repair with Laparoscopic-Supported Percutaneous Internal Ring Suturing Technique in Children - One Center Experience
}

\author{
Çocuklarda Laparoskopi Destekli Perkütan İç Halka Kapatılması \\ Tekniği ile Kasık Fıtığı Onarımı - Tek Merkez Deneyimi
}

Mehmet Ali NARSAT ${ }^{1}$, Ayse YILMAZ², Eren YILDIZ ${ }^{3}$

${ }^{1}$ Department of Pediatric Surgery, Kastamonu Training and Research Hospital, Kastamonu, Turkey

2Department of Anesthesiology and Reanimation, Kastamonu Training and Research Hospital, Kastamonu, Turkey

${ }^{3}$ Department of Pediatrics, Kastamonu Training and Research Hospital, Kastamonu, Turkey

\begin{abstract}
Objective: High ligation of the hernia sac is applied as the basic principle in inguinal hernia surgery. Nowadays, it is possible to perform inguinal hernia surgeries with minimally invasive methods and with the help of technological developments with the same success rates. One of these minimally invasive methods is the percutaneous internal ring suturing method, assisted by laparoscopy.

In this study, we aimed to present the case series that we treated with a laparoscopy-assisted percutaneous internal ring suturing and its results up to six months after surgery.

Material and Methods: Pediatric patients admitted to the Pediatric Surgery Clinic of Our Hospital with indirect inguinal hernia between November 01, 2019, and February 29, 2020, were included in the study. Patients with clinical features of incarcerated inguinal hernia were excluded from the study.

Inguinal hernia repair was performed by the percutaneous internal ring suturing method supported by laparoscopy.

Results: During the study period, 36 inguinal hernia repairs were performed in 27 patients. The distribution of age groups is over 24 months (8/27), 2-6 months (5/27), 6-12 months (4/27), and 12-24 months (1/27). No patient required open surgical technique or the use of additional trocars. The mean operation time was $24.3 \pm 1.77$ minutes. The mean hospitalization period of the patients was $2.15 \pm 0.12$ days.

During the follow-up of the patients, no recurrence, intra-abdominal complication, or inguinal complication was detected.

Conclusion: We found that the percutaneous internal ring closure method applied under laparoscopic support in childhood is an easy and safe method for indirect inguinal hernia repair.

Key Words: Inguinal hernia, Laparoscopic surgery, Minimally invasive surgery

öz

Amaç: Kasık fitı̆ı cerrahisinde, fitık kesesinin yüksek ligasyonu temel prensip olarak uygulanmaktadır. Günümüzde kasık fiıığı ameliyatlarının minimal invaziv yöntemlerle ve teknolojideki gelişmelerin yardımıla aynı başarı oranları ile yapılması mümkün olmaktadır. Bu minimal invaziv yöntemlerden biri de laparoskopi destekli perkütan iç halka kapatılması yöntemidir.
\end{abstract}

\section{(1)}

NARSAT MA : 0000-0002-6496-1965 YILMAZ A : :0000-0001-7635-0830 YILDIZE $\quad: 0000-0002-8056-5727$
Conflict of Interest / Çıkar Çatışması: On behalf of all authors, the corresponding author states that there is no conflict of interest.

Ethics Committee Approval / Etik Kurul Onayı: The approval of the Kastamonu University Clinical Research Ethics Committee, dated 26.11.2020 and numbered 2020-KAEK-143-02.01.

Contribution of the Authors / Yazarların katkısı: NARSAT MA: Constructing the hypothesis or idea of research and/or article, Planning methodology to reach the Conclusions, Taking responsibility in patient follow-up, collection of relevant biological materials, data management and reporting, execution of the experiments, Taking responsibility in logical interpretation and conclusion of the results, Taking responsibility in necessary literature review for the study, Taking responsibility in the writing of the whole or important parts of the study. YILMAZ A: Organizing, supervising the course of progress and taking the responsibility of the research/ study, Taking responsibility in patient follow-up, collection of relevant biological materials, data management and reporting, execution of the experiments, Taking responsibility in logical interpretation and conclusion of the results, Reviewing the article before submission scientifically besides spelling and grammar. YILDIZ E: Planning methodology to reach the Conclusions, Organizing, supervising the course of progress and taking the responsibility of the research/study, Taking responsibility in patient follow-up, collection of relevant biological materials, data management and reporting, execution of the experiments, Taking responsibility in logical interpretation and conclusion of the results, Reviewing the article before submission scientifically besides spelling and grammar.

How to cite / Atıf yazım şekli : Narsat MA, Yilmaz A, Yildiz E. Inguinal Hernia Repair with Laparoscopic-Supported Percutaneous Internal Ring Suturing Technique in Children - One Center Experience. Turkish J Pediatr Dis 2022; 16: 60-64.
Correspondence Address / Yazışma Adresi:

Mehmet Ali NARSAT

Department of Pediatric Surgery,

Kastamonu Training and Research Hospital, Kastamonu, Turkey

E-posta: malinarsat@gmail.com
Received / Geliş tarihi : :08.02.2021 Accepted / Kabul tarihi : 05.04.2021

Online published 18.06 .2021

Elektronik yayın tarihi

DOI: $10.12956 /$ tchd.876778 
Bu çalışmada, laparoskopi destekli perkütan iç halka kapatıması yöntemi ile tedavi ettiğimiz olgu serimizi ve ameliyat sonrası altı aya kadar olan sonuçlarını sunmayı amaçladık.

Gereç ve Yöntemler: Hastanemiz Çocuk Cerrahisi Kliniğine 01 Kasım 2019- 29 Şubat 2020 tarihleri arasında endirekt kasık fıtı̆ı ile bașvuran çocuk hastalar çalışmaya dahil edildi. İnkarsere kasık fıı̆̆ına ait klinik özellikleri taşıyan hastalar çalışma dışı bırakıldı.

Laparoskopi destekli perkütan iç halka kapatılıası yöntemi ile kasık fıtığı onarımı yapıldı.

Bulgular: Çalışmanın yapıldığı süre içerisinde 27 hastada 36 kasık fıı̆̆ı onarımı yapıldı. Yaş gruplarının dağılımı 24 ay üstü (8/27), 2-6 ay arası (5/27), 6-12 ay arası (4/27) ve 12-24 ay arası (1/27)'dir. Hiçbir hastada açık cerrahi tekniğe ya da ek trokar kullanılmasına gerek olmadı. Ortalama ameliyat süresi 24.3 \pm 1.77 dakikaydı. Hastaların hastanede ortalama yatış süresi $2.15 \pm 0.12$ gündü.

Hastaların takiplerinde rekürrans, karın içi komplikasyon ya da kasık bölgesinde komplikasyon saptanmadı.

Sonuç: Çocukluk çağında laparoskopi desteğinde uygulanan perkütan iç halka kapatma yönteminin endirekt kasık fıtığı onarımı için kolay ve güvenli olarak uygulanabilen bir yöntem olduğunu saptadık.

Anahtar Sözcükler: İnguinal herni, Laparoskopik cerrahi, Minimal invaziv cerrahi

\section{INTRODUCTION}

In inguinal hernia surgery, high ligation of the hernia sac has been used as the basic principle since the 19th century (1). This method, which is inadequate due to high recurrence rates in adults, has been used successfully for years of indirect inguinal hernia seen in childhood (2). Nowadays, it is possible to perform inguinal hernia operations with minimally invasive methods and with the same success rates with the help of technological developments (3). One of these minimally invasive methods is the laparoscopy-assisted percutaneous internal ring suturing (PIRS) method described by Patkowski et al. (4) in 2006. In this method, which can be applied without the need for any additional materials in clinics where pediatric laparoscopic surgeries are performed, inguinal hernia repair is performed percutaneously from the groin with the support of laparoscopy made from only one trocar incision.

In this study, we aimed to present the case series that we treated with the PIRS method supported by laparoscopy and its results up to six months after surgery.

\section{MATERIAL and METHOD}

After the approval of the local ethics committee, dated 26.11.2020 and numbered 2020-KAEK-143-02.01, the data of pediatric patients who applied to the Pediatric Surgery Clinic of our hospital between 01 November 2019 and 29 February 2020 were retrospectively evaluated and included in the study. Patients with clinical features of incarcerated inguinal hernia were excluded from the study.

Inguinal hernia repair was performed using the PIRS method supported by laparoscopy (4-5).

\section{Operation steps}

Under general anesthesia, $5 \mathrm{~mm}$ and $30^{\circ}$ laparoscopy optic was advanced through the umbilical incision with the aid of a reusable trocar under $5 \mathrm{mmHg}$ intraabdominal pressure setting. The appearance of the inguinal canals and their openness were evaluated (Figure 1-A). The 21G injection needle, used as a guide, was advanced from the lateral of the inguinal canal to the preperitoneal area carrying the carrier loop suture material (Figure 1-B, C). The guide needle was advanced between the carrier loop suture material, taking care not to take it into the spermatic cord from the medial of the inguinal canal, and the carrier loop suture material was placed on the guide needle (Figure 1-D). The ligature suture material, which was advanced through the guide needle, was released and was taken out of the body with the help of loop suture material (Figure 1-E, F). As the binding material, 3/0 non-absorbable mono-fiber suture material was used in children under the age of three, and 2/0 non-absorbable monofilament suture material was used in children over the age of three. The closure of the internal inguinal ring was checked and the intervention in the groin area was terminated when it was observed that it was closed (Figure 1-G). In the case of accompanying umbilical hernias, umbilical hernia repair was also performed.

The patients were followed up in the sixth month after the operation. During this control, the relatives of the patients were asked to visually evaluate the umbilical incision between "1 worst view" and " 5 best views" and it was recorded in the file. Apart from the surgeon who performed a similar evaluation, another doctor was made and recorded in the file.

The demographic characteristics of the patients, preoperative and postoperative findings, operation time, treatment costs, and surgical complications were collected and recorded.

\section{RESULTS}

During the study period, 36 inguinal hernia repairs were performed in 27 patients. In our patient series, the most operated age group was under 2 months (9/27). The distribution of other age groups in order of frequency is over 24 months (8/27), 2-6 months (5/27), 6-12 months (4/27), and 12-24 months (1/27). The mean age of the patients was calculated as $2.78 \pm 4.53$ years, $2.00 \pm 4.74$ for males and $4.10 \pm 4.04$ for females.

In the preoperative examination, an inguinal hernia was most frequently detected on the right side (15/27). The distribution of 


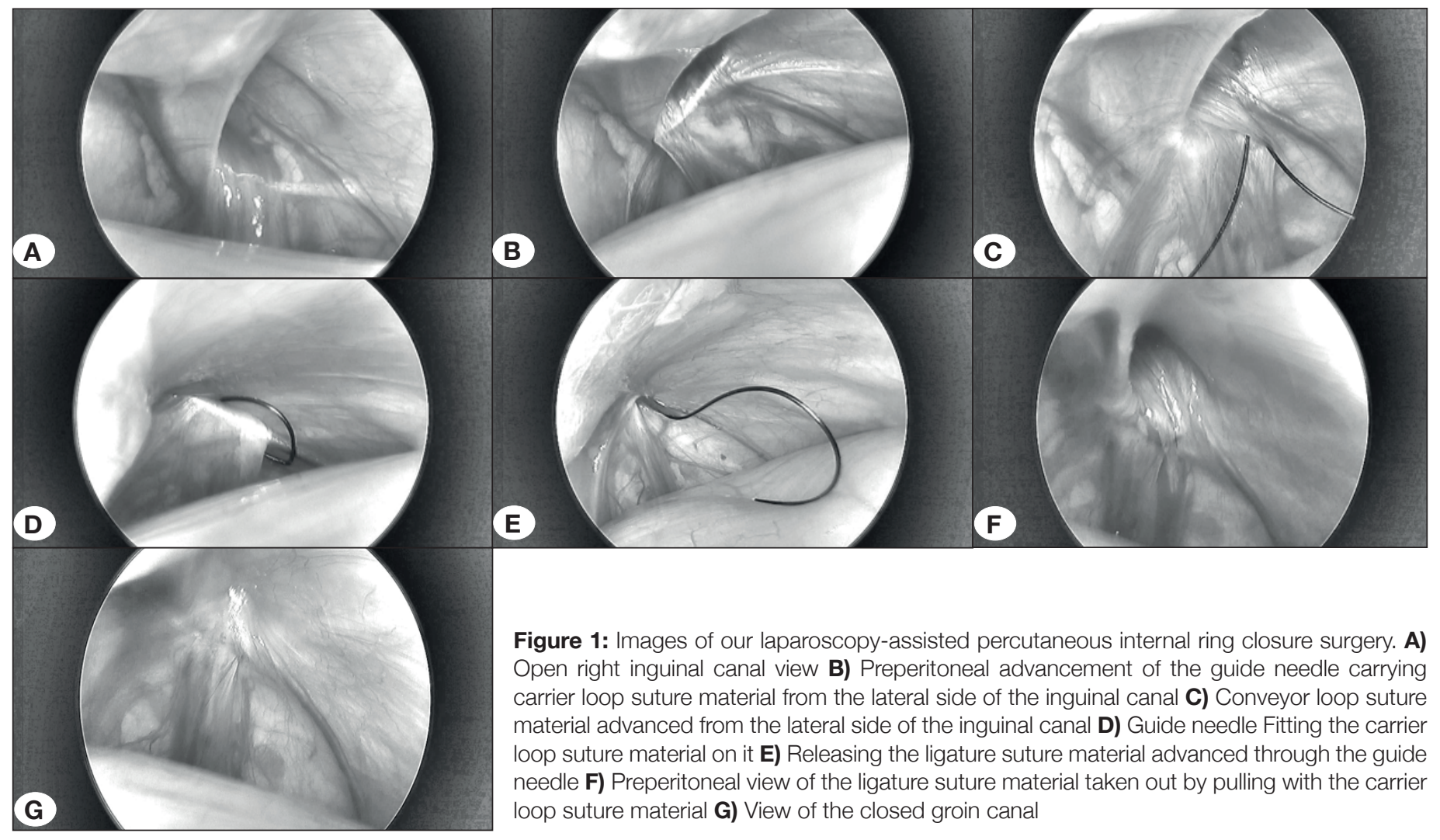

the side of the hernia by gender in patients is shown in Table I. There were four patients with contralateral inguinal hernia when the abdomen was inflated with pressure during the operation. Three of these patients had preoperative left inguinal hernia findings. Patent processus vaginalis openings in patients without swelling in the inguinal region in pressure inflation were not recorded.

Surgery was completed with $5 \mathrm{mmHg}$ intraabdominal pressure in 10 patients. Considering all patients, the mean intraabdominal pressure value used was found to be $8.07 \pm 0.52$ $\mathrm{mmHg}$. Preperitoneal bleeding developed in one patient during the operation. After the bleeding was controlled with tampon application, the repair was completed. No patient required open surgical technique or the use of additional trocars. The mean operation time was $24.3 \pm 1.77$ minutes (male 23.59 7.55 and female $25.50 \pm 11.91$ ). The average length of stay of the patients in the hospital was $2.15 \pm 0.12$ days. The average treatment cost per patient was calculated as $1799 \pm 92$ Turkish Lira.

During the follow-up of the patients, no recurrence, intraabdominal complication, or inguinal complication was detected. Skin infection developed in the umbilical incision in one patient. None of the patients had skin scar in the groin area in the control examination performed in the sixth month. In six patients, it was found that the prolene knot material could be palpated subcutaneously. In the examination of the male patients, the testicles were in an age-appropriate size and the scrotum. The visual assessment of the umbilical incision was
Table I: Distribution of the side with the hernia by gender ( $n=27$ ).

\begin{tabular}{l|c|c|c|c|}
\hline & Right & Left & Bilateral & Total \\
\hline Male & 12 & 2 & 3 & 17 \\
Female & 3 & 5 & 2 & 10 \\
\hline Total & 15 & 7 & 5 & 27 \\
\hline
\end{tabular}

scored as an average of $4.74 \pm 0.12$ by the patient's relative and $4.0 \pm 0.12$ by the doctor whose opinion was taken.

\section{DISCUSSION}

In the laparoscopy-assisted PIRS attempt performed in 36 inguinal hernias in 27 cases we performed in our hospital for a period of four months, the preperitoneal bleeding that occurred in one patient during the surgery was a complication other than the skin infection occurring in the umbilical incision in one patient and especially hernia recurrence not observed. With these results, our intraoperative and postoperative 3.7\% minor complication rate and recurrence results are similar to previous studies $(4,5)$.

The inguinal hernia has traditionally been performed with open technique and high ligation for years. However, laparoscopic methods, which have been used primarily for recurrence and bilateral hernia surgeries, have been used more frequently in parallel with the increase in the number and experience of the surgeons performing (6). However, in laparoscopic repairs 
performed using three ports as previously described, the difficulty of knot application for closing the inguinal canal and the fact that the total size of the incisions made for the port reached the size of the open technique prevented its spread (7).

The use of a single port of $5 \mathrm{~mm}$ or even $3 \mathrm{~mm}$ in the PIRS technique and the easy application of the node used to close the internal ring eliminated the negative aspects of laparoscopic methods previously described and used for hernia repair $(4,5$, $8,9)$. In our series of 27 patients with nine patients younger than two months, we did not experience any difficulties or negativities in using this method.

Another advantage of the PIRS method is that the inguinal hernias on the contralateral side that do not show any symptoms before surgery, and even if the patient has an accompanying umbilical hernia, can be repaired simultaneously using a single incision. In the recent publications of Miyake et al. (10) And also Dreuning et al. (7), It is suggested that the ongoing discussions about the exploration of the opposite side in repairs performed with the open technique will disappear with the widespread use of the PIRS method. In our series, hernia repair was performed on the contralateral side simultaneously in four patients who were not detected in the preoperative examination but were found to have an inguinal hernia on the contralateral side during surgery. Also, an umbilical hernia detected in three patients was simultaneously repaired in the same session and using the same incision.

No significant intra-abdominal complications associated with the PIRS method have been reported in the literature (7). We did not observe any intraabdominal complications during the surgery. In our series, prolene suture material is palpated subcutaneously in six patients during follow-up. In a study in 2020, in who Patkowski was also one of its authors, it was reported that both non-absorbable monofilament and nonabsorbable polyfilament suture materials were used (11). This situation made us think that the authors faced similar problems. In this study of the authors, granuloma occurred in a patient in which they used nonabsorbable polyfilament suture material, and reoperation was required for the granuloma. In our series, palpation of the stitches did not cause any problem for any patient or parents. However, it was seen that the method should be evaluated and developed in this respect.

After the previously described and applied laparoscopic inguinal hernia repair method, the average length of stay stated in the studies is higher than the open method; however, there was no difference in operative time between the two methods $(12,13)$. We did not compare the operation time, length of stay, and treatment cost with any other laparoscopic or open method that we determined in our series. However, both the operation time, the duration of stay, and the treatment cost were within acceptable limits and the morbidity rate did not increase significantly. Since the average length of stay of the patients in the hospital is calculated as days, the hospital stay of the patients who are followed up overnight appears to be two days. The follow-up of pediatric patients operated under general anesthesia by staying in the hospital for 24 hours is a routine approach in our hospital. Even if we do not apply it, patients who are operated under general anesthesia can be discharged on the same day. If this method is preferred, the duration of hospital stay will be shorter.

When the open method is applied, there is no obstacle to using the recurrence open method. Recurrence of hernia beyond the age of six years was detected after the series. However, the small sample size of our case series does not allow us to generalize. In their study published by Thomas et al. In Istanbul (8), they predict that the complication and recurrence rates will decrease as the method continues to be used and one experience is gained.

Although evaluations regarding the damage of testicular tissue and the spermatic cord in male patients are dangers that need to be considered, no scrotal complications were found in our study, and no reduction in testicular size was observed in the six months $(14,15)$.

Even within a period of six months, the skin incision made for the umbilical port entry has almost regained its normal appearance and reached a cosmetically perfect result as determined by the scoring of both the patient's parents and an independent physician. This result we obtained in our series is in line with the results of the research published by Chen et al.(16) regarding this method in 2020.

In addition to the limitations of all retrospective studies, our study does not offer the opportunity to compare the results within itself, since it was conducted with a single patient group. According to what Wolak mentioned in his publication, the technique is easier to apply in female patients (5). However, in our study, the mean duration of operation was longer in female patients. Another limitation of the article is that the factors affecting the operation time are not recorded. However, in the light of the evaluated literature and the results of our own series, it is seen that the PIRS technique is a safe method, despite minor complications.

\section{CONCLUSION}

We found that the PIRS method applied under laparoscopic support in childhood is an easy and safe method for indirect inguinal hernia repair. In our small case series, we did not observe any significant complications related to hernia or scrotum both during the operation and in the six-month postoperative period. These results suggest that this method can be a candidate to replace the open method because it is reliable and applicable. However, long-term studies with large series are required to 
investigate the results of laparoscopy-assisted percutaneous internal ring repair as much as the open method applied for more than a century and to reveal the problems that may occur.

\section{REFERENCES}

1. Lau WY: History of treatment of groin hernia. World J Surg 2002;26:748-59.

2. Sachs M, Damm M, Encke A: Historical evolution of inguinal hernia repair. World J Sur 1997;1:218-23.

3. Schier F, Montupet $\mathrm{P}$, Esposito C: Laparoscopic inguinal herniorrhaphy in children: a three-center experience with 933 repairs. J Pediatr Surg 2002;37:395-7.

4. Patkowski D, Czernik J, Chrzan R, Jaworski W, Apoznański W. Percutaneous internal ring suturing: a simple minimally invasive technique for inguinal hernia repair in children. J Laparoendosc Adv Surg Tech A 2006;6:513-7.

5. Wolak PK, Patkowski D. Laparoscopic inguinal hernia repair in children using the percutaneous internal ring suturing techniqueown experience. Wideochir Inne Tech Maloinwazyjne 2014;9:53-8

6. Danielson J, Pakkasjärvi N, Högberg N. Percutaneous Hernia Repair in Children: Safe to introduce. Scand J Surg 2020:1457496920918151.

7. Dreuning K, Maat S, Twisk J, van Heurn E, Derikx J. Laparoscopic versus open pediatric inguinal hernia repair: state-of-the-art comparison and future perspectives from a meta-analysis. Surg Endosc 2019;1:3177-91.

8. Thomas DT, Göcmen KB, Tulgar S, Boga I: Percutaneous internal ring suturing is a safe and effective method for the minimal invasive treatment of pediatric inguinal hernia: experience with 250 cases. J Pediatr Surg 2016;51:1330-5.
9. Tanger R, Singh AP, Gupta AK, Mathur V. Laparoscopic inguinal hernia repair in girls using the percutaneous internal ring suturing technique-our own experience. Menoufia Med J 2020;33:713-6.

10. Miyake H, Fukumoto K, Yamoto M, Nakajima H, Sekioka A, Yamada $Y$, et al. Risk factors for recurrence and contralateral inguinal hernia after laparoscopic percutaneous extraperitoneal closure for pediatric inguinal hernia. J Pediatr Surg 2017;52:317-21.

11. Frýbová B, Trčka J, Dotlačil V, Poš L, Patkowski D, Rygl M. Laparoscopic inguinal hernia repair in children via PIRS (percutaneous internal ring suturing). Řešení tříselné kýly u dětí technikou PIRS (percutaneous internal ring suturing). Rozhl Chir 2020;99:277-81.

12. Takehara H, Yakabe S, Kameoka K. Laparoscopic percutaneous extraperitoneal closure for inguinal hernia in children: clinical outcome of 972 repairs done in 3 pediatric surgical institutions. J Pediatr Surg 2006;41:1999-2003.

13. Timberlake MD, Herbst KW, Rasmussen S, Corbett ST. Laparoscopic percutaneous inguinal hernia repair in children: review of technique and comparison with open surgery. J Pediatr Urol 2015;11: 262.e1-262.e6

14. Pogorelić Z. Effects of laparascopic hernia repair by PIRS (percutaneous internal ring suturing) technique on testicular artery blood supply. J Investig Surg 2018;12:348-9.

15. Oral A, Karaca L, Ahiskalioglu A, Yildiz A, Yigiter M, Celikkaya ME, et al. Effects of laparoscopic hernia repair by PIRS (Percutan Internal Ring Suturing) technique on testicular artery blood supply. J Invest Surg 2019;32: 343-7.

16. Chen JC, Zhang QL, Chen L, Wang YJ, Huang WH, Zhou CM Single-port laparoscopic percutaneous closure of the internal ring for scarless repair of inguinal hernias in girls. Minim Invasive Ther Allied Technol 2020:1-7. doi: 10.1080/13645706.2020.1768124. 